\title{
A NEW GENUS AND SPECIES OF GEMPYLIDAE (PISCES : PERCIFORMES) FROM TONGA RIDGE
}

\author{
$\operatorname{AUTHOR}(\mathrm{S})$ :
}

Nakamura, Izumi; Fujii, Eiichi

\section{CITATION:}

Nakamura, Izumi ... [et al]. A NEW GENUS AND SPECIES OF GEMPYLIDAE (PISCES

PERCIFORMES) FROM TONGA RIDGE. PUBLICATIONS OF THE SETO MARINE BIOLOGICAL LABORATORY 1983, 27(4-6): 173-191

ISSUE DATE:

1983-01-31

URL:

http://hdl.handle.net/2433/176057

RIGHT: 


\title{
A NEW GENUS AND SPEGIES OF GEMPYLIDAE (PISGES: PERGIFORMES) FROM TONGA RIDGE ${ }^{1)}$
}

\author{
IzUMI NAKAMURA ${ }^{2)}$ \\ Division of Fishes, Department of Vertebrate Zoology, NMNH, Smithsonian Institution \\ and \\ EIrich FUJII \\ Suruga Bay Marine Biological Society, Tokai University
}

With Text-figures $1-13$ and Table 1

During the research cruise of R.V. Kaiyo Maru, which the junior author (EF) joined around the Tonga Ridge area in the South Pacific, in 1977, a number of gempylid fish were caught in one haul of an otter trawl out of five hauls. This gempylid first seemed to be a second species of the monotypic genus Thyrsitops, because it has a similar appearance and counts to those of Thyrsitops lepidopoides. 'There are some morphometric differences between the species: our gempylid has a semifusiform and robust body, and $T$. lepidopoides has a much more compressed and slender body: Careful study revealed that the gempylid species obtained from the Tonga Ridge is referable to a new genus and new species and that it has both gempylid and scombrid characteristics as discussed later... This species could be a key species in considering interrelationships between Gempylidae and 'Scombridae. Therefore, osteological features are described in detail.

\section{Material and Methods}

Material used in this study were the 38 specimens caught in one trawl haul in the Tonga Ridge area (Fig. 1). Measurements followed Nakamura, Fujii and Arai (1983), and counts were taken in accordance with Hubbs and Lagler (1958). One specimen (FRSKU S-2323, $218 \mathrm{~mm}$ SL) was cleared and stained for osteological observations. Radiographs of the holotype and the several paratypes were used for additional osteological observations and counting vertebráe. Abbreviations used for the institutions cited here are as follows: AMS, Australian Museum, Sydney; FRSKU, Fisheries Research Station, Kyoto University; Maizuru; NSMT, National Science Museum, Tokyo; USNM, United States National Museum of Natural History, Smithsonian Institution, Washington, D.C.; ZMUT, Zoological Museum, University of Tokyo, Tokyo.

1) Contributions from the Seto Marine Biological Laboratory, No. 686.

2) Present address: Fisheries Research Station, Kyoto University, Maizuru, Kyoto 625.

Publ. Seto Mar. Biol, Lab., XXXVII (4/6), . 173-191, 1983.

(Article. 10) $\therefore \cdots$ 


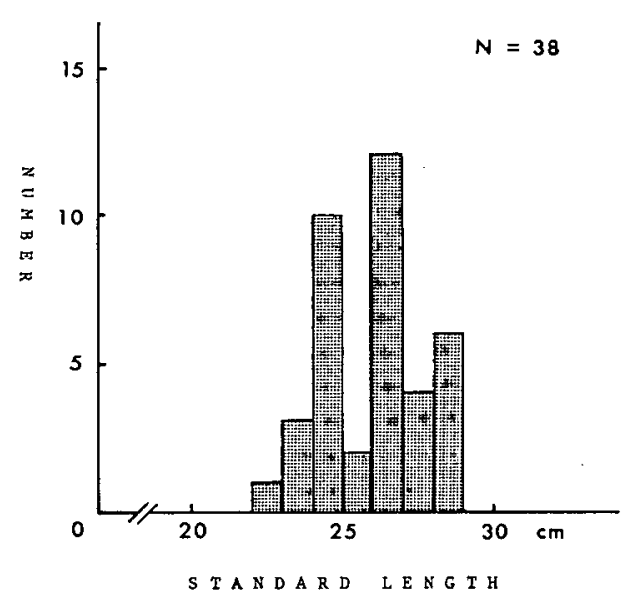

Fig. 1. Body length frequency histogram of Tongaichthys robustus obtained from Tonga Ridge, the South Pacific.

\section{Tongaichthys, new genus}

Type-species: Tongaichthys robustus, new species

Diagnosis: Tongaichthys shows the most similar external resemblance to Thyrsitops and next to Thyrsites among the genera of Gempylidae. This genus, however, can be distinguishable from Thyrsitops in a considerable number of characters (see Discussion) and from Thyrsites chiefly in the following characters: fewer number of dorsal fin spines (16-17 in Tongaichthys vs. 20-2l in Thyrsites); more number of dorsal fin soft rays (14-17 vs. 10-11); more number of pectoral fin rays (17-19 vs. 14-15); more robust and semifusiform vs. more slender body; fairly straight lateral line vs. more undulate lateral line. Tongaichthys is easily distinguishable in many characters from any other genera of Gempylidae.

Etymology: Tonga from the type-locality and ichthys, fish in Greek.

\section{Tongaichthys robustus, new species}

(Figs. 2-13)

Holotype: NSMT-P19758, $254 \mathrm{~mm} \mathrm{SL}$, one of 38 specimens caught by R.V. Kaiyo Maru at 17th trawl station of her western South Pacific Cruise on the Tonga Ridge, $22^{\circ} 10.8^{\prime} \mathrm{S}, 175^{\circ} 23.6^{\prime} \mathrm{W}$; Jan. 11, 1977; 12:25-13:25 hrs.; 312-288 m; bottom condition: flat, sands and shells; surface temperature: $26.4^{\circ} \mathrm{C}$; bottom temperature: $17.3^{\circ} \mathrm{C}$; bottom salinity: $35.5 \%$; trawling speed: 3.8 knots; trawling distance: 3.8 miles; warp length: $950 \mathrm{~m}$; height of mouth of net ca. $5 \mathrm{~m}$; width of mouth of net $24 \mathrm{~m}$.

Paratypes: FRSKU S-2311, S-2312, S-2318 and S-2319, 4 specimens, 209-254 mm SL; NSMT P-19759-P-19762, 4 specimens, 200-247 mm SL; ZUMT 5425454256, 3 specimens, 201-223 mm SL; AMS I 22523-001, 22523-002, 2 specimens, 
216, $233 \mathrm{~mm}$ SL; USNM 227336, 2 specimens, 231, $242 \mathrm{~mm}$ SL: all 15 paratypes with same location and data as holotype.

Diagnosis: Body semifusiform and only slightly compressed. Scales on cheek enlarged, elongate and slightly overlapping. Head very large, about 3.2 times in SL. Snout short and rather blunt. One or two (rarely three) small fangs on anterior maxilla. No fangs on lower jaw. A pair of faint keel-like processes on caudal base. Number of pectoral fin rays 17-19. Principal caudal fin rays 19. Caudal fin rays cover hypural complex deeply but not completely. A small pineal foramen present. A minute predorsal present.
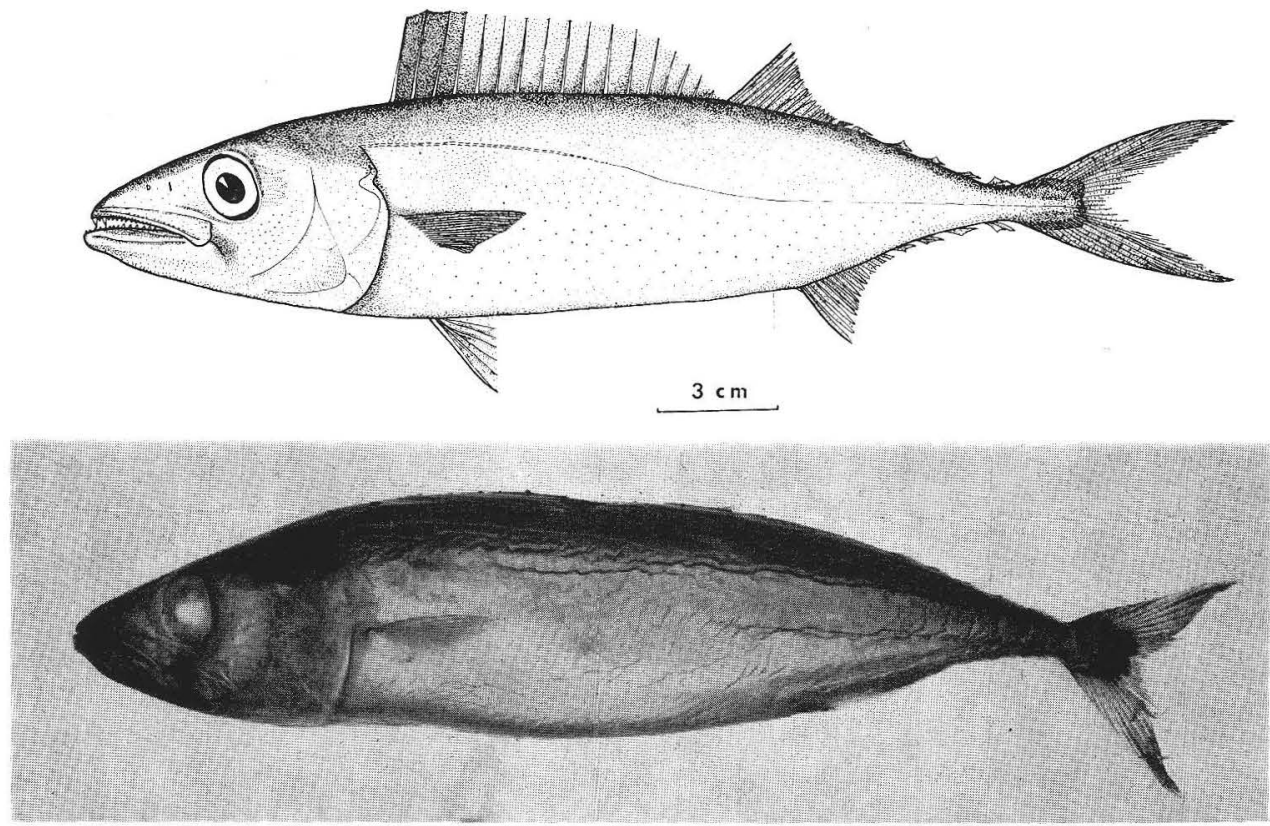

Fig. 2. Tongaichthys robustus, holotype NSMT-P19758, $254 \mathrm{~mm} \mathrm{SL(top);} \mathrm{a} \mathrm{specimen} \mathrm{from} 38$ of T. robustus caught by R.V. Kaiyo Maru (bottom).

Description: Holotype followed by paratypes in parenceses: dorsal fin rays XVII, 15+6 (XVI-XVII, 14-17+5-6); anal fin rays I, $14+5$ (I, 14-16+5-6); pectoral fin rays i, 17 (i, 16-18); pelvic fin rays I, 5 (I, 5); principal caudal fin rays 19 (19); gill rakers $5+1+8(4-6+1+7-11)$; branchiostegals $7(7)$; vertebrae $18+15=$ $33(18+15=33)$.

Measurements expressed as percent of SL: head length 31.3 (31.3-32.5); snout length 11.9 (11.9-12.7); length of upper jaw 13.0 (12.6-13.5); horizontal eye diameter $6.1(5.5-6.7)$; vertical eye diameter $6.3(6.0-7.0)$; horizontal fleshy orbit diameter 5.6 (5.1-6.1); vertical fleshy orbit diameter 6.3 (6.2-7.0); interorbital width 6.3 (6.0-6.6); depth of caudal peduncle 3.3 (3.2-3.8) ; length of caudal peduncle 28.2 (27.5-30.1); longest first-dorsal spine 8.6 (7.7-10.4); longest second-dorsal ray 7.6 (7.1-8.0); longest anal ray $6.3(5.6-7.4)$; length of pectoral fin 13.4 (13.1-14.0); length of pelvic fin 9.9 (9.8-10.8); body depth 23.5 (22.3-23.9); body width 11.6 (11.4-13.7); 
first predorsal length 32.7 (31.6-34.4); second predorsal length 66.5 (66.2-69.4); prepectoral length 31.6 (31.4-32.6); prepelvic length 37.3 (36.9-38.9); preanal length 74.7 (73.2-75.7); preanus length 71.4 (69.8-72.5); length of abdomen 39.6 (36.140.7); length of first-dorsal fin base 35.6 (34.3-37.9); length of second-dcrsal fin base 14.0 (11.7-14.6); length of anal fin base $11.1(9.7-13.0)$.

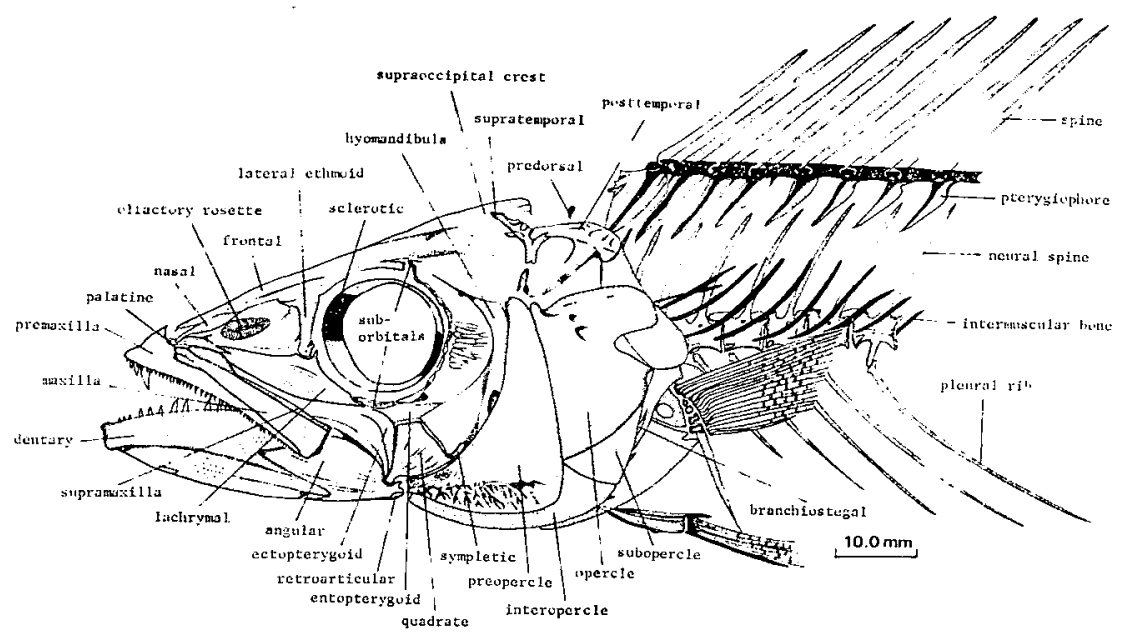

Fig. 3. Lateral view of head of Tongaichthys robustus

The following description is based on the holotype and paratypes. Body semifusiform (Fig. 2) and slightly compressed. Very deciduous fine cycloid scales on body and postorbital region. Scales on cheek enlarged, elongate and slightly overlapping (Fig. 3). Lateral line scales modified into incomplete tube-like structures (Fig. 4). Head very large, about 3.2 in SL. Snout short and rather blunt, lower jaw projecting slightly beyond upper jaw. Mouth stout and not protractile, end of maxilla just extending below anterior edge of eye. One or two (rarely three) small fangs and 1 or 2 scars (presumably of missing fangs) on anterior part of each maxilla, none depressible except middle one in case of three. No fangs on lower jaw. Lateral teeth on both jaws uniserial, compressed and caniniform, those of lower jaw (about 10) larger and more widely spaced than those of upper jaw (about 40). Middle teeth larger than anterior and posterior teeth on both jaws. About 30 small canini-

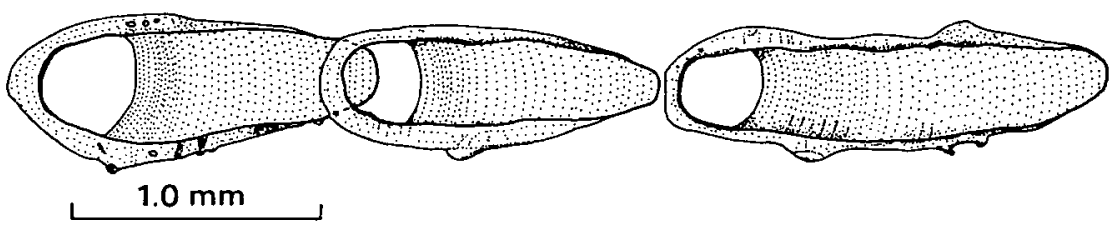

Fig. 4. Lateral line scales on anterior part of lateral line of Tongaichthys robustus (pore at anterior end).

form teeth on each palatine. About 13 small caniniform teeth on vomer. Gill rakers spinescent, with many fine spinules on their bases; numerous irregular fine 


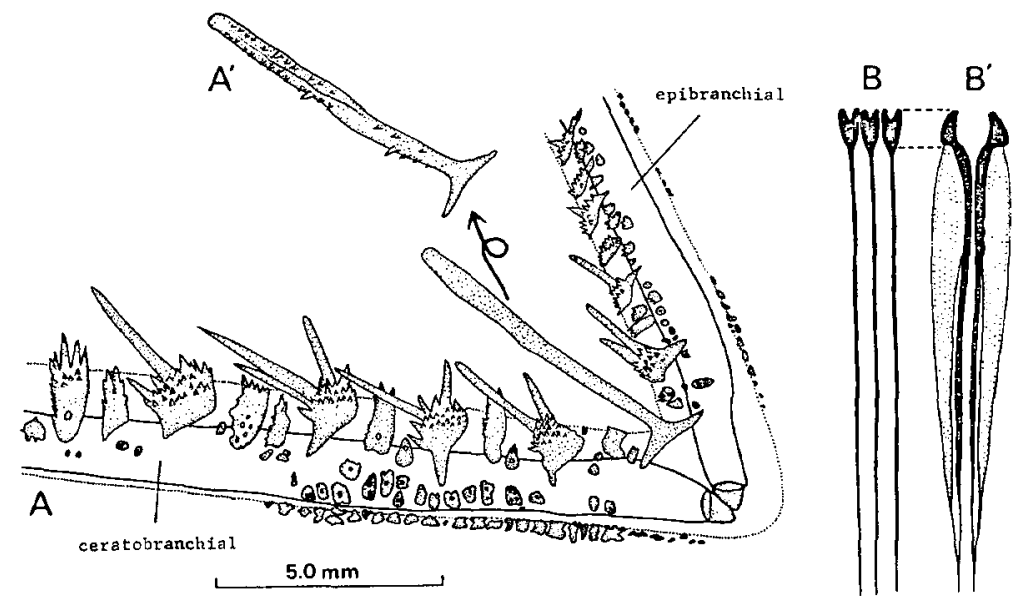

Fig. 5. External view of left first gill arch of Tongaichthys robustus (A). A' showing inner side of the raker at angle. Gill rays on midpart of ceratobranchial in lateral (B) and posterior (B') views.

bony plates on gill arches (Fig. 5A). Longest raker with two rows of fine spinules on its inner surface, located at angle of first arch (Fig. 5A'). Gill arches with numerous gill filaments arranged in two rows, each gill filament supported by a partly ossified blade-like gill ray (Fig. 5B, $\mathrm{B}^{\prime}$ ). Pseudobranchial filaments well developed. Skin of opercular bones finely serrate, but opercular bones themselves not serrate. Left and right gill membranes not united to each other, free from isthmus. Nostrils small and well separated, anterior one semi-lunate and posterior one slit-like. Olfactory rosette consists of about 42 olfactory laminae arranged transversely (Fig. 3). Eye large, situated nearer tip of snout than hind margin of opercle. Interorbital region flat with a $\mathrm{V}$ shaped furrow posteriorly. Lateral line single, gradually descending from above upper margin of opercle to base of caudal fin with slight undulations. First dorsal fin moderately high and its origin above anterior insertion of pectoral fin, its base a little longer than that of second dorsal fin (including finlets). Dorsal fin spines soft and feeble. Second dorsal fin rather low with 5 to 6 finlets posteriorly. Both dorsal and anal finlets triangular in shape. Anal fin rather low with a minute spine anteriorly and several finlets posteriorly. Pectoral fin small and situated rather low. Pelvic fin well developed and slightly shorter than pectoral fin, inserted below hind insertion of pectoral fin. Caudal-peduncle depth short, less than eye diameter. Gaudal fin stout but rather small, a pair of keel-like processes slightly developed on caudal base. Soft fin rays of all fins segmented.

Viscera: Pyloric caeca 26-28 sac-shaped tubules, forming a small caecal mass (Fig. 6A). Liver large with three lobes; right lobe massive and most elongate, twice as long as left and middle lobes; middle lobe massive and short, and left lobe slender and short (Fig. 6B). Spleen visible in ventral view, situated behind posterior part of caecal mass. Gall bladder an elongate tubular sac, situated between posterior part of right lobe of liver and spleen. Intestine relatively short and straight. Stomach long and large, extending to near anus. Swim bladder absent. 


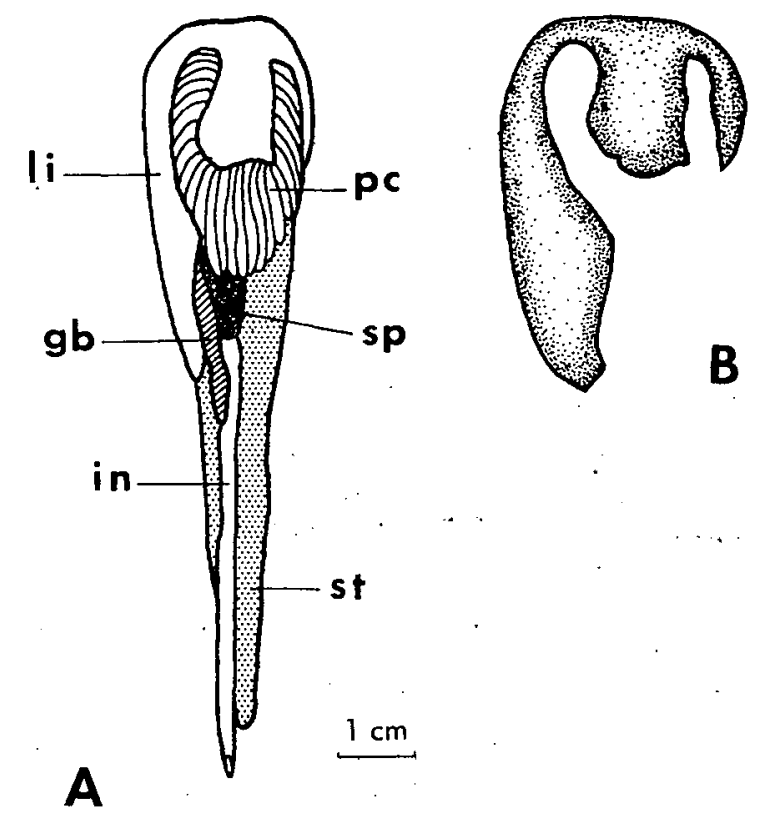

Fig. 6. Viscera (A) and liver (B) of Tongaichthys robustus, USNM 227336-2; $242 \mathrm{~mm}$ SL in ventral view. gb: gall bladder; in: intestine; li: liver; pc: pyloric caeca; sp: spleen; st: stomach.

Color (in formalin): Body dark brown above, slightly paler below. Dorsal part of head, hind part of end of upper jaw, upper margin of lower jaw, inner base of pectoral and base of caudal brown black. Anterior three or four first dorsal fin membranes and proximal parts of other membranes black. Upper margin of pectoral fin and anterior margin of second dorsal fin slightly darkened. Other fins paler. No remarkable markings or spots on body.

Etymology: The name robustus is from robust in Latin, because of the semifusiform and robust body of this species.

Biological notes: It seems likely that $T$. robustus forms tight school as most scombrids do, because fair numbers of similar sized specimens were caught by one haul of trawl (Fig. 1). Their swimming depth is estimated to be about $300 \mathrm{~m}$ deep from the surface, unless they were caught when hauling the net up. Stomach contents of three specimens examined show empty (two specimens) and a digested myctophid fish, gen. and sp. unknown (one specimen). Gonads of two spccimens examined arc not well developed yet.

Osteological features: Osteological terminology generally follows Collette and Ghao (1975).

An articulated skull with surrounding bones is shown in Fig. 3. Mandibular arch composed of upper jaw (premaxilla, maxilla and supramaxilla) and lower;jaw (dentary, angular and retroarticular). Caniniform teeth on premaxilla and dentary. Premaxilla slightly curved and elongate with an arrowhead-like.anterior end and 
teeth on ventral margin. Maxilla also slightly curved and elongate with two irregularly shaped condyles articulated with anterodorsal part of premaxilla and a thin anterodorsal process. Thin and elongate supramaxilla covers posterior part of maxilla. Dentary stout with a dorsal dentigerous process and a ventral process, between which anterior part of angular inserted. Angular (often called articular) stout with a large triangular mid process firmly inserted into dentary, an elongate anterodorsal process and a small spine-shaped anteroventral process. Small rhomboid-shaped retroarticular (often called angular) attached firmly to posteroventral margin of angular.

Palatine arch composed of four pairs of bones in roof of mouth: palatine, ectopterygoid, entopterygoid and metapterygoid. Slender palatine with an anterior condyle which meets anterior part of nasal and anterodorsal part of premaxilla and with small teeth on ventral margin, posteriorly sturdily connecting with ectopterygoid and partly with entopterygoid. Slender Y-shaped ectopterygoid (often called pterygoid) united anteriorly with posterior part of palatine and posteriorly with both entopterygoid and quadrate. Thin expanded plate-shaped entopterygoid (often called mesopterygoid) united anteriorly with ectopterygoid and palatine partly, ventrally with dorsal part of quadrate and anterodorsal part of metapterygoid. Flat triangular metapterygoid articulated firmly with hyomandibular posteroventrally, with entopterygoid anterodorsally and with symplectic posteroventrally.

Hyoid arch composed of hyomandibular, symplectic, quadrate and hyoid complex (hypohyal, ceratohyal, epihyal, interhyal, and seven branchiostegals), and unpaired median glossohyal (often called basihyal) and urohyal. Wedge-shaped hyomandibular connecting mandibular suspensorium and opercular bones to neurocranium. Small rod-shaped symplectic surrounded by quadrate, metapterygoid and preopercle. Flat fan-shaped quadrate with an anteroventral condyle which suspends lower jaw by articulating with a socket of posterodorsal parts of angular. Detail of hyoid complex shown in Fig. 7. Hypohyal composed of a dorsal and a ventral part firmly fused to each other along a serrate suture, possessing internal process at anterodorsal surface articulated with glossohyal, first basibranchial and urohyal. Elongate and flat

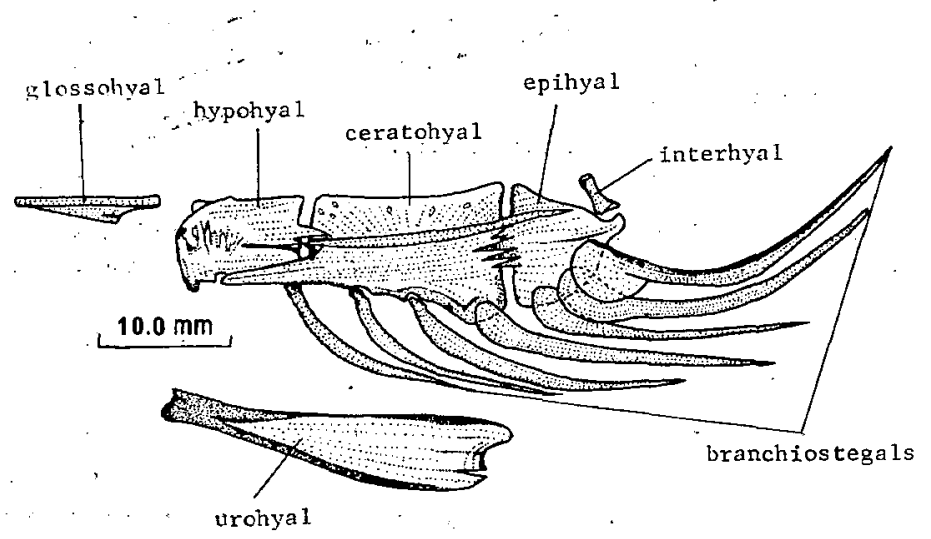

Fig. 7. Hyoid arch of Tongaichthys robustus, external view of left side. 
ceratohyal with deeper posterior portion, slightly concave dorsal portion and two small notches for receiving branchiostegals on ventral portion, firmly articulating with hypohyal anteriorly and epihyal posteriorly along serrate sutures. A deep longitudinal groove extends along upper third of ceratohyal from middle of hypohyal to upper part of epihyal. Triangular epihyal with a posterior condyle articulated with inner surface of interopercle, inter-locking medially with ceratohyal. Small rod-shaped interhyal attached to dorsal portion of epihyal condyle, connecting hyoid complex to the other bones of hyoid arch and opercular bones with connective tissue. Spatulate glossohyal underlying tongue and overlying first basibranchial. Flat elongate urohyal connected to left and right hypohyals with connective tissue. Anterior four branchiostegals attached to ventral margin of ceratohyal and posterior three to ventral part of epihyal. All branchiostegals more or less flat, proximal base of posterior three very flat and wide.

Opercular apparatus composed of opercle, subopercle, preopercle and interopercle. Four wide flat opercular bones fit together to form gill cover. Opercle somewhat squarish, with a deep notch on posterior margin. Thin triangular subopercle covered by opercle dorsally, by preopercle anteriorly and by interopercle ventrally. Large lunate preopercle thickened along its anterior margin for attaching with hyomandibular, symplectic and quadrate, with reticulate canals on ventral portion. Elongate triangular interopercle mostly covered by preopercle.

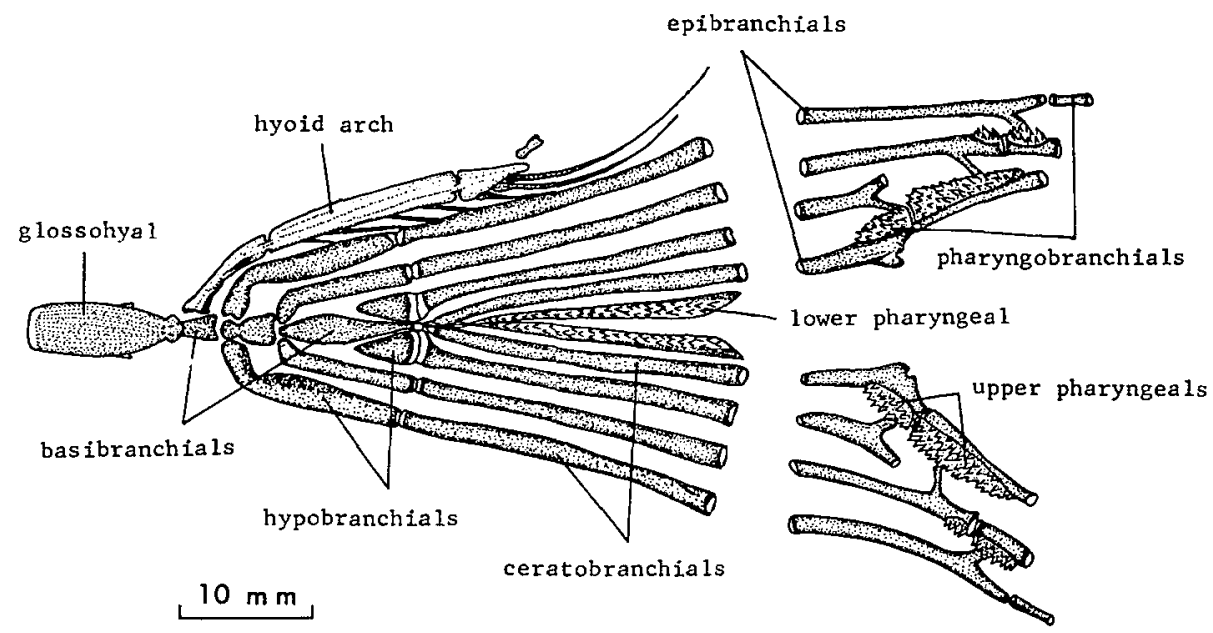

Fig. 8. Branchial arch of Tongaichthys robustus. Dorsal view of gill arches with dorsal halves folded back to show their ventral aspect. Epidermis removed. Right hyoid arch only shown.

Branchial arch composed of five pairs of gill arches with gill filaments, gill rakers, pharyngeal tooth patches and supporting bones (Fig. 8). Three basibranchials articulated with each other by cartilages interspaced to form a longitudinal series; first and second about the same size and considerably shorter than third. First three gill arches have hypobranchials connected posteriorly with ceratobranchials; first hypobranchial anteriorly to second basibranchial and second and third hypobranchials to 
third basibranchial; first hypobranchial largest, third shortest. Ceratobranchials, longest bones in branchial arch, supporting most gill filaments and gill rakers; anterior three similar in shape and size, articulating to posterior ends of respective hypobranchial with cartilages; fourth slightly shorter than anterior three, attaching to a cartilage posterior to third basibranchial; fifth ceratobranchial often called lower pharyngeal with a tooth plate on its entire length, attaching to a cartilage posterior to third basibranchial. Four epibranchials attached basally to posterior portion of respective ceratobranchials with cartilages, various in shape and more or less forked; first longest, second a little shorter than first, and third and fourth shortest and stubbier. Four pharyngobranchials attached basally to epibranchials respectively; slightly recurved first pharyngobrancial articulated dorsally with parasphenoid and often called suspensory pharyngeal; second small and rod-shaped with a small patch of teeth; third and fourth have dermal tooth plates fused to them and called upper pharyngeals. Small spinescent gill rakers on hypobranchial, ceratobranchial and epibranchial of first to four gill arches (Fig. 5). Small spinescent inner gill rakers and/or series of tubercles on hypobranchials, ceratobranchials and epibranchials of all gill arches. Interarcual cartilage (Johnson, 1980) and a cartilage between second epibranchial and third pharyngobranchial present.

Neurocranium with a pair of pterotic crests, a pair of parietal crests and a supraoccipital crest, roughly elongate triangular in dorsal view (Fig. 9), and divided into four major regions, ethmoid, orbital, otic and basicranial.

Ethmoid region composed of unpaired ethmoid and vomer and paired lateral ethmoids and nasals. Ethmoid (often called dermethmoid or mesethmoid) located most anterodorsally in neurocranium, shield-like in dorsal view with an anterior and a pair of lateral processes, overlapped posteriorly by frontals and connecting ventrally to vomer and posteriorly to lateral ethmoids with rough and porous sutures. Dentigerous vomer located most anteroventrally in neurocranium, articulating with ethmoid and lateral ethmoids dorsally and with v-shaped anterior projection of parasphenoid posteriorly. Massive lateral ethmoid (often called prefrontal or parethmoid) with posterolateral process attached to lachrymal, ectopterygoid and entopterygoid, and articulating with ethmoid anterodorsally, with frontal posterodorsally, with parasphenoid posteroventrally and with vomer anteroventrally. Roughly bottle-shaped nasal articulated with anteroventral part of frontal and engraved by small sensory canals.

Orbital region composed of paired frontals and pterosphenoids, unpaired basisphenoid and a paired series of lachrymal (first suborbital) and remaining suborbitals and sclerotics. Large flat frontal forms most of dorsal surface of neurocranium, overlapping ethmoid, lateral ethmoid and pterosphenoid anteriorly and articulating with supraoccipital, parietal, pterotic and sphenotic posteriorly; a small round pineal foramen inbetween anterior and posterior slits between left and right frontals. Flat irregular shaped pterosphenoid (often called alisphenoid) articulated anteriorly with frontal and posterior wall of brain case and a part of roof of orbit. Y-shaped basisphenoid articulated dorsally with prootics and pterosphenoids and ventrally with 


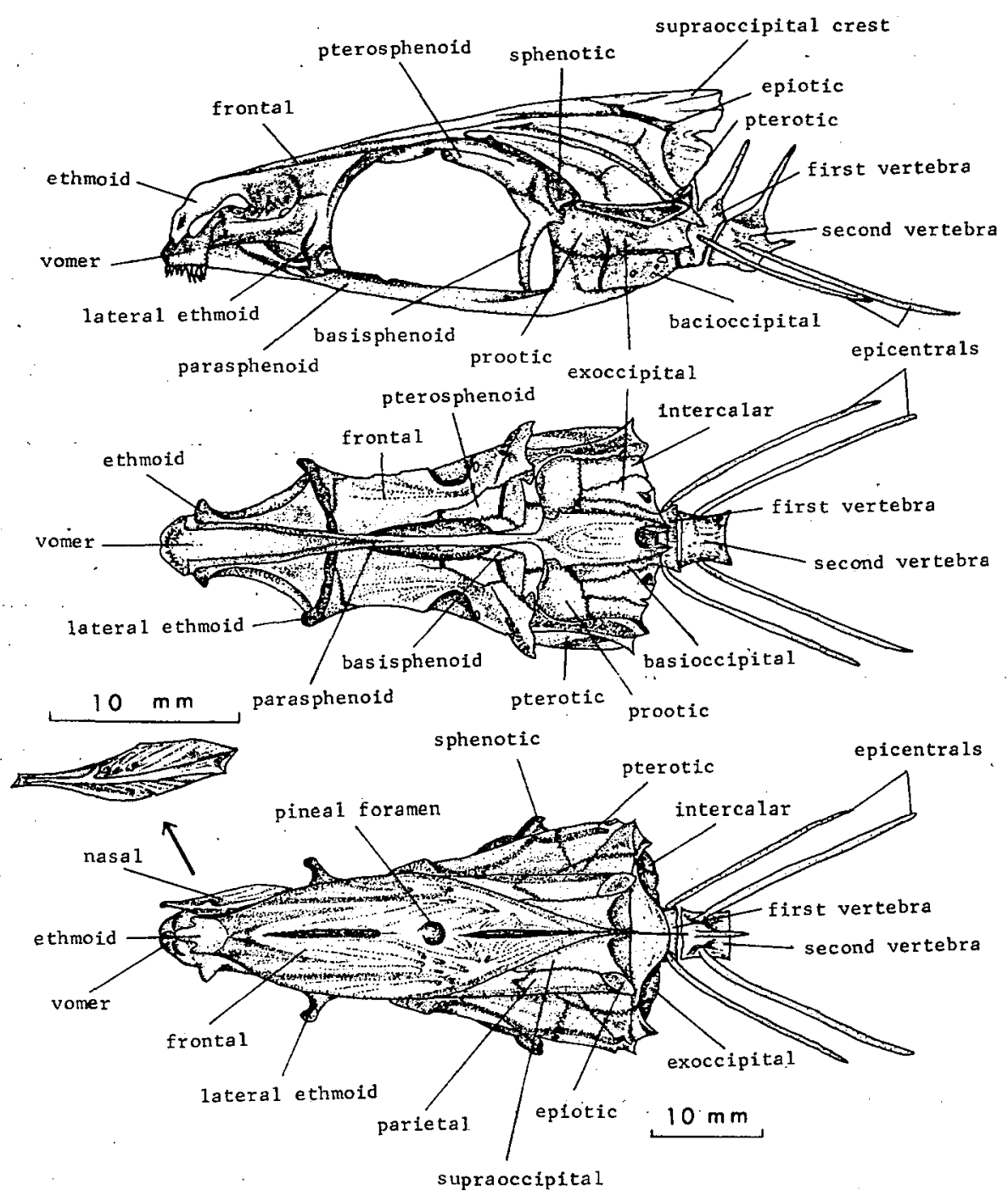

Fig. 9. Skull of Tongaichthys robustus in lateral (top), ventral (middle) and dorsal (bottom) views.

parasphenoid. Triangular thin lachrymal has an anterior bifurcation attached to anterodorsal part of maxilla, a dorsal socket for receiving a ventrolateral condyle of lateral ethmoid, and posterior splinter-like process attached to second suborbital (Fig. 3). A series of suborbitals (about 14) with sensory canals surrounding posterior half of eye (Fig. 3). Sclerotic consists of two small ossified segments connected by two large cartilage bones (Fig. 3).

Otic region composed of paired parietals, epiotics, pterotics, prootics, sphenotics, and intercalars plus unpaired supraoccipital. Thin rhomboidal parietal articulated with frontal anteriorly, with pterotic laterodorsally, with supraoccipital lateroproxi- 
mally, with sphenotic ventrally and with epiotic posteriorly. Massive irregular epiotic articulated with parietal anteriorly, with supraoccipital lateroproximally, with exoccipital posteriorly and with pterotic laterodorsally; medial process of posttemporal attached to flat dorsal part of epiotic. Pterotic with small spiny process posteriorly, located most posterolaterally on neurocranium, articulating with epiotic and parietal medially and exoccipital and intercalar posteriorly and receiving ventral process of supratemporal posterodorsally. Irregular and rather large prootic articulated with all ventral bones composing posteroventral part of neurocranium. Sphenotic with lateral process, articulating with frontal anteriorly, with pterosphenoid medially, with prootic and pterotic posteriorly and parietal dorsomesially. Intercalar (often called opisthotic) with a small dorsal protuberance connected to lateral process. of posttemporal, located between exoccipital and pterotic. Median supraoccipital with a thin triangular dorsal crest and a massive basal part, articulating with frontals anteriorly, with.parietals laterally and with epiotics and exoccipitals posteriorly.

Basicranial region composed of paired exoccipitals, unpaired median parasphenoid and basioccipital. Exoccipital connects neurocranium to first vertebra dorsally, surrounding foramen magnum, articulating with supraoccipital, epiotic and prootic anteriorly, with intercalar laterally and with basioccipital ventrally. Long parasphenoid with paired midlateral wings attached firmly with anteroventral part of prootics, anterior bifurcation articulated with vomer, ethmoid and lateral ethmoid, a posterior wider base bifurcated into two lateral flanges which attach dorsally to corresponding posteroventral flanges of basioccipital and surround posterior opening of posterior myodome, and a medial shaft attached to basisphenoid dorsally in front of midlateral wings. Most posteroventrally located U-shaped basioccipital with posterior flanges fitted ventrally to lateral flanges of parasphenoid to form roof and lateral walls of posterior myodome, articulating anteriorly with prootics and dorsally with exoccipitals; lateral flanges fuse with each other posteriorly to form a circular margin attached to margin of first vertebral centrum.

Vertebral column shown mostly in Fig. 10 and partly in Figs. 3 and 9. Centra massive and stout. Neural spines stout and laterally flattened at tip of 23rd to 28th vertebrae. Haemal spines begin on 19th vertebra, that of 19 th vertebra laterally flattened on mid portion, those of 25 th to $28 \mathrm{th}$ vertebrae flattened on tip. Neural and haemal spines bend backward and cover some neural and haemal grooves posteriorly to merge into caudal complex. Neural prezygapophyses on first vertebra modified to articulate with exoccipital. Neural prezygapophyses developed from third vertebra and postzygapophyses from second vertebra to preural vertebrae two and four, respectively. Neural prezygapophyses larger than postzygapophyses, both overlapping with each other firmly. Haemapophyses (pre- and post-zygapophyses) arise from 6th vertebra and gradually become larger, then smaller until preural vertebra four, not overlapping each other. Haemal arch (closed condition) present from 10th to 18th vertebrae, first two arches directed anteriorly, then several arches vertical and last three arches directed posteriorly. No parapophyses developed. Pleural ribs present from third vertebra posterior to 8th vertebra. Intermuscular bones 


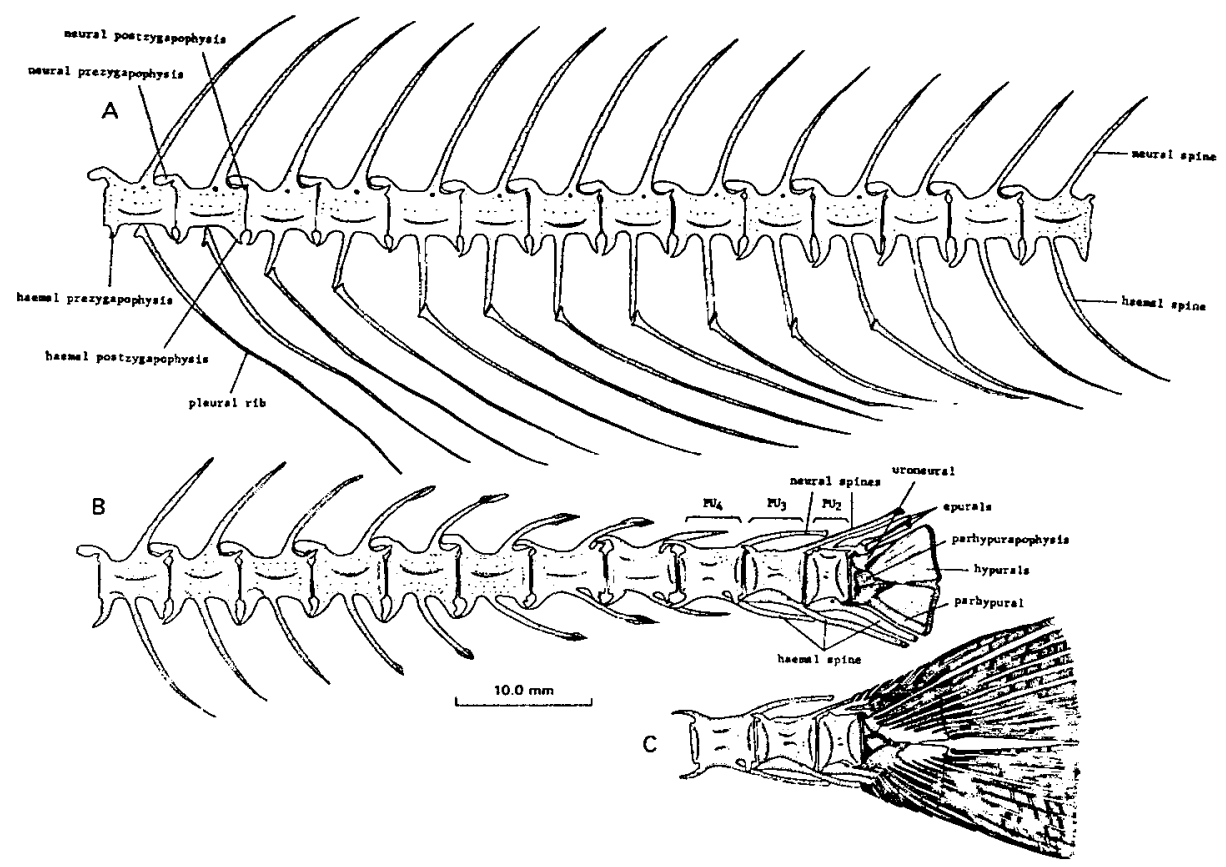

Fig. 10. Vertebrae of Tongaichthys rohustus in lateral view. A showing 8th to 21 st vertebrae, B showing 22 nd to last vertebrae, and $G$ showing last four vertebrae with caudal fin rays.

(epicentrals) start on first vertebra and extend to 11 th vertebra, but not attached to neurocranium as in higher scombrid fishes.

Supporting bones of caudal fin (Fig. $10 \mathrm{~B}, \mathrm{C}$ ) consists of three preural centra. Preural centrum three has a stout elongate rod-shaped non-autogenous neural spine and a stout rod-shaped autogenous haemal spine. Preural centrum two reduced about half of previous one in length and has a low neural spine attached to one of three epurals and a stout flattened autogenous haemal spine. Urostyle, theoretically derived from a preural centrum and two ural centra (Nybelin, 1973), fused with uroneural anterodorsally and fused indistinguishably with hypurals bearing an autogenous parhypural ventrally. An elongate triangular uroneural fused firmly to anterodorsal part of hypural plate ventrally. Three small rod-shaped epurals attached with each other firmly between haemal spine of preural centrum three and uroneural. Parhypural with a massive hooded process (parhypurapophysis) anterodorsally, located between autogenous haemal spine of preural centrum two and anteroventral margin of hypural plate and not fusing with hypural plate. Triangular hypural plate composed of fused hypural bones, possessing a deep hypural notch and with an anterior fine suture anterior to hypural notch and a fine slit just below hypural notch. Neural and haemal spines of preural vertebrae two and three bend away from vertebral axis and parallel dorsal and ventral edges of hypural plate. Caudal-fin rays cover hypural complex deeply but not completely (Fig. $10 \mathrm{C}$ ).

Dorsal and anal-fin rays and finlets supported by corresponding pterygiophores. Each pterygiophore of fin ray consists of a single radial except first ray of second 

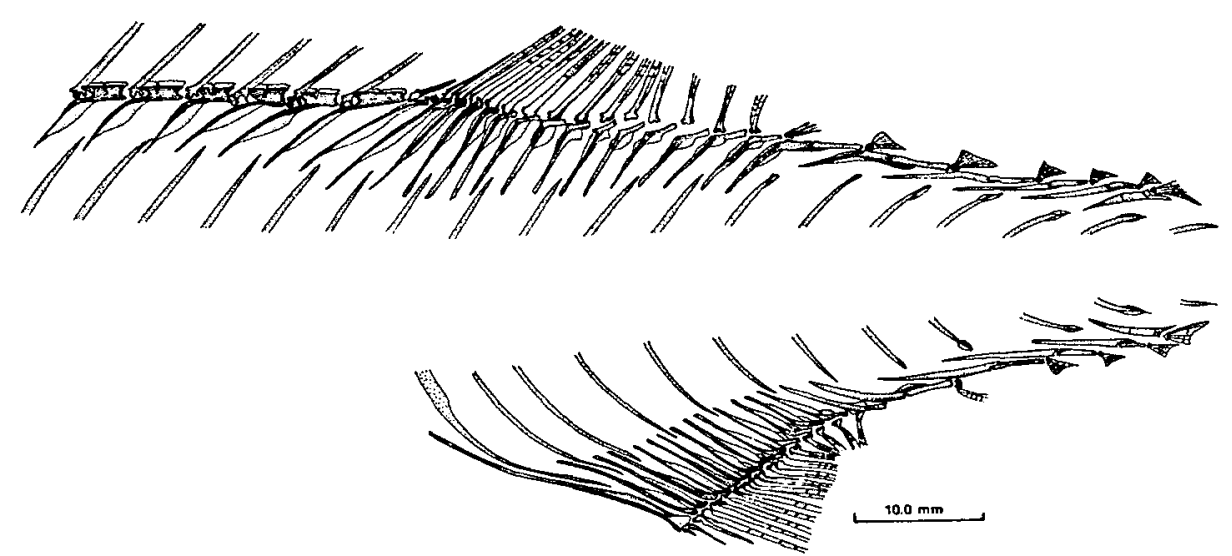

Fig. 11. Dorsal and ventral pterygiphores with neural and haemal spines of Tongaichthys robustus in lateral view.

dorsal fin with a small distal radial in addition to a large proximal radial, and each pterygiophore supporing finlets consists of two (proximal and distal) radials except last dorsal and anal finlets with proximal, medial and distal radials and a single stay (Figs. 3 and 11). First pterygiophore of first dorsal fin situated between first and second neural spines.

Pectoral girdle composed of cleithrum, scapula, coracoid, posttemporal, supratemporal, supracleithrum, first postcleithrum, second postcleithrum and four radials (Fig. 12). Posttemporal with two anterior (median and lateral) processes and flat

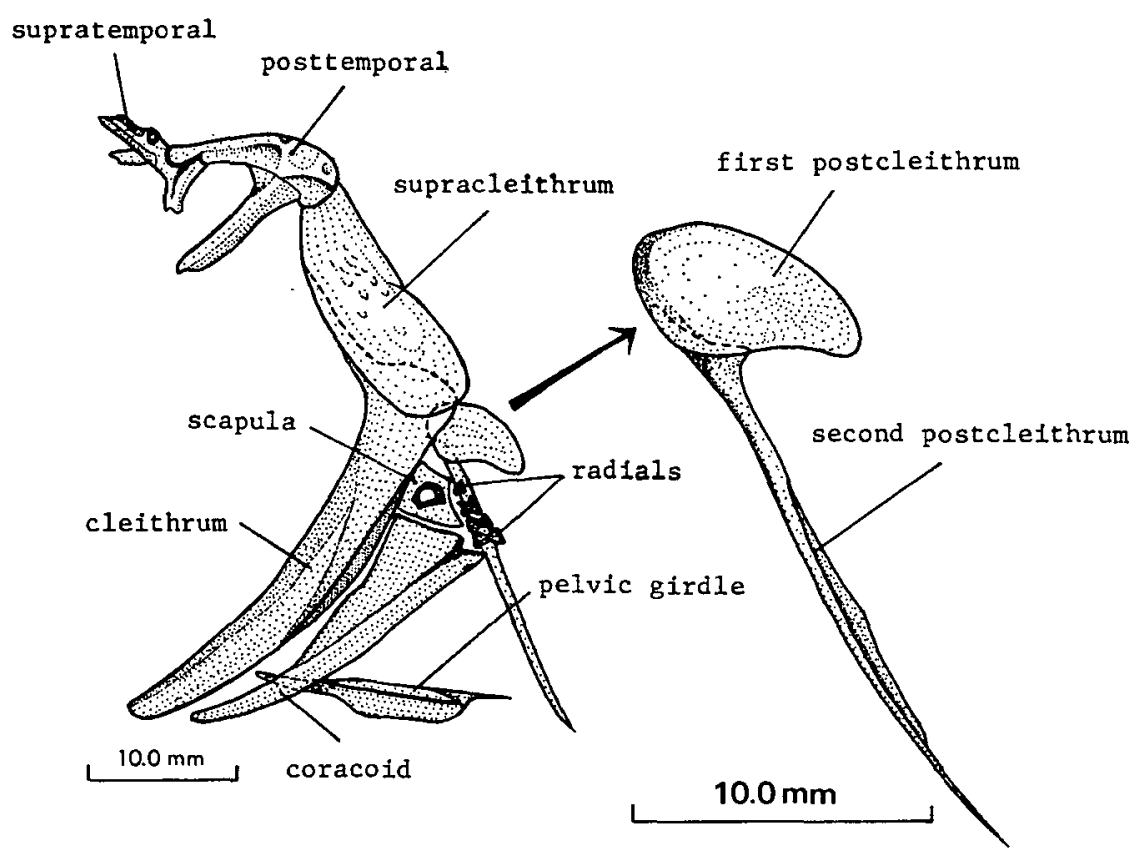

Fig. 12. Pectoral girdle of Tongaichthys robustus, left lateral view. 
posterior base, thin median process articulated with epiotic; rod-shaped lateral process articulated with intercalar. Thin supratemporal with two anterior (dorsal and ventral) processes and posterior process, each ventral process attached to dorsoposterior part of pterotic; posterior process overlaps median process of posttemporal. Lateral line canals present on supratemporal and median process and posterior base of posttemporal. Elongate oval supracleithrum located between posttemporal and cleithrum. Crescent-shaped stout cleithrum with an anterodorsal spine overlapped by anteroventral part of supracleithrum, an outer shelf forming body of cleithrum and an inner shelf articulated posteriorly with coracoid and scapula. Roughly rhomboid scapula with a foramen, articulating anteriorly with cleithrum, ventrally with coracoid and posteriorly with three radials; posterodorsal margin of scapula has a facet for receiving anterior rays of pectoral fin. Elongate triangular coracoid with a dorsoposterior notch for receiving fourth radial, articulating dorsally with coracoid and anteriorly with cleithrum, and attached firmly to an anterior process of pectoral girdle internally at about one-third from ventral tip and to posterior margin of urohyal with ligament. Postcleithrum composed of two parts (first and second or dorsal and ventral); flat and oval first postcleithrum attached to posterodorsal margin of cleithrum internally; flat and elongate second postcleithrum attached to four radials internally. Four radials differ in size and shape, attaching to posterior margins of scapula and coracoid and touching second postcleithrum.

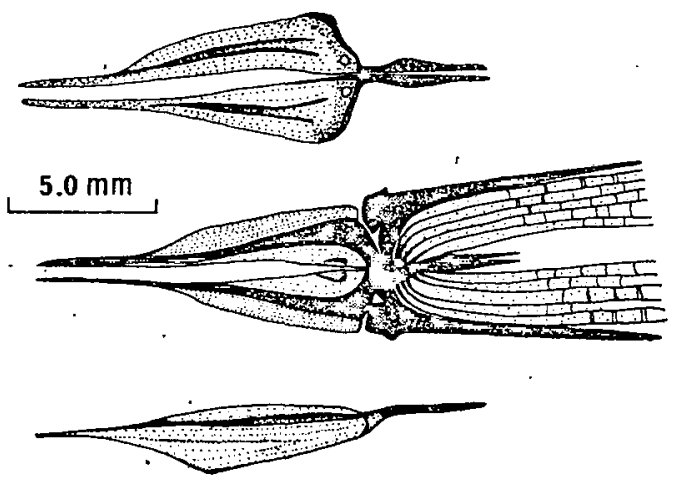

Fig. 13. Pelvic girdle of Tongaichthys robustus in dorsal (top), ventral (middle), and lateral (bottom) views. ...

Pelvic girdle composed of a pair of basipterigia, each with an anterior process, a wide basal part and a posterior styliform process (Fig. 13), external part of anterior process attaching firmly to cleithrum (Fig. 3).

\section{Discussion}

At first we were puzzled about which family, Gempylidae or Scombridae, we should put Tongaichthys robustus in, because its condition of the hypural plate deeply covered (but not completely covered) by caudal fin rays (Fig. 10. C) is not seen in 
any species of Gempylidae. Although we felt T. robustus to be a gempylid based on its external appearance. Collette (1978) reported, "In the Scombridae, the caudalfin rays insert over and completely cover the hypural plate instead of merely inserted on the margins of the hypural plate as in the Gempylidae". From this point of view, the condition of hypural plate of $T$. robustus is intermediate between those of Scombridae and Gempylidae. T. robustus also possesses a considerable number of both gempylid and scombrid characteristics as well as intermediate characteristics discussed later on. We finally decided to put this species in the family Gempylidae because it is more similar to Thyrsitops lepidopoides of Gempylidae than to any other species of Gempylidae and Scombridae and shares many important characters with $T$. lepidopoides: no fangs on anterior part of lower jaw; a single nearly straight lateral line; first dorsal fin soft and feeble with 16 to 17 spines; pelvic fin well-developed with fin rays, I, 5; no detached spine in front of anal fin; triangular fan-shaped dorsal and anal finlets, 5 to 6 respectively; no dermal process on tip of jaws; a dark blotch behind end of upper jaw; total vertebrae 33; epicentrals present but no epinurals or epipleurals; a predorsal bone present; head and body dark dorsally and pale ventrally.

On the other hand, Tongaichthys robustus is distinct from Thyrsitops lepidopoides in the following characters: depth and width of body larger; head larger; eye larger; cheek scales enlarged, elongate and slightly overlapping; small fangs on tip of upper jaw (large fangs in T. lepidopoides); first dorsal higher; position of pelvic fins more anterior; pectoral fin rays more than 17; a pair of faint caudal keel-like processes on caudal fin base; more pyloric caeca; hypural plate more deeply covered by caudal fin rays.

For evaluating the character states of $T$. robustus based on both external and internal characteristics, its 53 characters were compared with those of both Gempylidae and Scombridae (Table 1). Eighteen characters of T. robustus (2, 5, 9, 11, 18, $19,21,23,25,30,31,33,34,35,37,38,48$ and 53) are similar to the Gempylidae, 11 characters $(1,6,15,27,32,36,39,42,44,51$ and 52) to the Scombridae and 14 characters $(3,4,8,12,14,16,17,20,24,26,40,41,46$ and 47) are intermediate between the Gempylidae and Scombridae. The other 10 characters (7, 10, 13, 22, $28,29,43,45,49$ and 50 ) are rather difficult to evaluate. It is interesting to point out that this species has much more important characters as a gempylid $(2,11,19$, $23,34,48$ and 53$)$ than as a scombrid $(6,42,51$ and 52$)$.

In spite of the several comprehensive studies (Matsubara and Iwai, 1952, 1958; Parin and Bekker, 1972), the family Gempylidae still has some problems at the species level ańd its generic inter-relationships has not been known well. In spite of the studies by Regan (1909), Starks (1910), Kishinouye (1923) and Fraser-Brunner -(1950) the mutual relationships of the Scombridae are not yet fully understood. Although B.B. Collette (Personal communication) has nearly completed a study of the relationships of Scombridae and J.L.:Russo (Personal communication) is now studying intergeneric relationships of Gempylidae, it is not possible at this time to discern the exact phylogenetic position of Tongaichthys robustus. We feel now that $T$ : robustus is: related to the primitive scombrid genera, Rastrelliger, Scomber and 
Table 1. Comparison of certain characteristics of Tongaichthys with those of Gempylidae and Scombridae

\begin{tabular}{|c|c|c|c|c|}
\hline & Characters & Tongaichthys & Gempylidae & Scombridae \\
\hline 1. & Body form & $\begin{array}{l}\text { Semifusiform and slightly } \\
\text { compressed }\end{array}$ & $\begin{array}{l}\text { Compressed except Leipidocybium and } \\
\text { Ruvettus (semifusiform) }\end{array}$ & Fusiform or semifusiform \\
\hline 2. & Fangs on jaws & $\begin{array}{l}\text { One or two small fangs on } \\
\text { upper jaw }\end{array}$ & $\begin{array}{l}\text { Large fangs present except } \\
\text { Lepidocybium (no fang) }\end{array}$ & Absent \\
\hline 3. & Caudal keels & Faint caudal keel-like processes & $\begin{array}{l}\text { Absent except Lepidocybium (a peduncular } \\
\text { keel) and Thyrsitoides (faint caudal keel-like } \\
\text { process) }\end{array}$ & $\begin{array}{l}\text { Paired caudal keels or a peduncular } \\
\text { keel with paired caudal keels }\end{array}$ \\
\hline 4. & Caudal fin rays & Cover most of hypural complex & Cover marginal part of hypural complex & Completely cover hypural complex \\
\hline 5. & Principal caudal fin rays & Segmented & Segmented & $\begin{array}{l}\text { Not segmented except lower scombrids } \\
\text { (slightly segmented) }\end{array}$ \\
\hline 6. & No. of principal caudal fin rays & 19 & 17 & $17-19$ \\
\hline 7. & Corselet & Absent & Absent & Present in higher scombrids \\
\hline 8. & Cheek scales & Slightly overlapping & $\begin{array}{l}\text { Not overlapping except Lepidocybium and } \\
\text { Gempylus }\end{array}$ & Overlapping \\
\hline 9. & Interpelvic process & Absent & Absent & Present (single or double) \\
\hline 10. & Lateral line & Single & $\begin{array}{l}\text { Single (largely undulated in Lepidocybium) } \\
\text { or double }\end{array}$ & Single except Grammatorcynus (double) \\
\hline 11. & Dorsal fin spines & Soft and feeble & Soft and feeble or moderately strong & Strong and pungent \\
\hline 12. & Groove for first dorsal fin & Moderately deep & $\begin{array}{l}\text { Shallow or moderately deep (Lepidocybium } \\
\text { and Ruvettus) }\end{array}$ & Deep \\
\hline 13. & Detached anal spines & Absent & Present or absent & Absent except some lower scombrids \\
\hline & Dorsal and anal finlets & Present $(5-6 / 5-6)$ & Absent or present $(2-6 / 2-6)$ & Present $(5-9 / 5-9)$ \\
\hline 15. & Shape of finlet & Triangular in shape & $\begin{array}{l}\text { Elongate except Lepidocybium and Thyrsitops } \\
\text { (triangular) }\end{array}$ & Triangular \\
\hline 16. & Position of pectoral fin & Middle or slightly low & Low & High \\
\hline & No. of pectoral fin rays & $17-19$ & $12-17$ & $18-36$ \\
\hline & Shallow cavity for pectoral fin & Absent & Absent & Present \\
\hline & Inner pectoral flap & Absent & Absent & Present except in some lower scombrids \\
\hline 20. & Pelvic fin & Well developed & Reduced, poorly developed or well developed & Well developed \\
\hline & Shallow cavity for pelvic fin & Absent & Absent & Present \\
\hline & Dermal flaps on tip of jaws & Absent & Present or absent & Absent \\
\hline & Gill rakers & Spinous & Spinous & $\begin{array}{l}\text { Normal (not spinous) or absent } \\
\text { (Acanthocybium) }\end{array}$ \\
\hline 24. & Gill rays & Partly developed & Not developed or partly developed & Well developed \\
\hline & Marks on body & No prominent mark present & Absent & Present \\
\hline
\end{tabular}


26. No. of pyloric caeca

27. Liver

28. No. of vertebrae

29. No. of branchiostegals

30. Lateral line scales

31. Supramaxilla

32. Socket on ethmoid

33. Suborbitals

34. Opercle

35. Ceratohyal window

36. Glossohyal

37. Latero-posterior wings of glossohyal

38. Upper pharyngeal teeth

39. First postcleithrum

40. Second postcleithrum

41. Supraoccipital crest

42. Pineal foramen

43. Parietal foramen

44. Preural centrum two

45. Parhypural

46. Hypurals

47. Hypural notch

48. No. of hypurals

49. Epineurals and epipleurals

50. Predorsals

51. Neural prezygapophysis

52. Haemal pre- and postzygapophysis

53. Position of first dorsal pterygiophore
26-28

Very large with three lobes

$$
18+15=33
$$

7

Tube-like

Elongate splint-like

Present

Tube-like

A deep notch posteriorly

\section{Absent}

Wide

Present

No stay inbetween

Flattened

Moderately elongate

Moderately developed

Small one present

Absent

Reduced in length

Separate from hypurals
Less than 16 except Lepidocybium (numerous)

Usually small, three lobes inconspicuous

31-37 except Gempylus, Diplospinus and

Paradiplospinus (49-66)

7-8

Tube-like

Elongate splint-like

Absent except Lepidocybium and Ruvettus

Tube-like except Lepidocybium (flat plate)

A deep notch posteriorly

Usually absent

Narrow except Lepidocybium (wide)

Present except Lepidocybium

No stay inbetween

Slender except Lepidocybium

Moderately to largely elongate

Poorly developed except Lepidocybium and Neoepinnula

Absent

Absent

Not reduced or slightly reduced in length

Separate from hypurals

Forming a hypural plate almost Not forming a hypural plate

A deep and narrow notch A wide notch present

(or slit) present

3

Absent

Small one present

Flattened

Well developed

Between first and second neural spines
2 or 3

Present or absent

Absent except Ruvettus and Thyrsilops

Pointed

Poorly or moderately developed

Between first and second neural spines
400 or more

Very large, three lobes except Scomber and Rastrelliger

38-63 except Rastrelliger, Scomber and Grammatorcynus (31)

7

Not tube-like

Absent or small flat (not splint-like)

Present

Not tube-like, flat plate

No notch except Rastrelliger, Scomber and

Grammatorcynus (a shallow notch)

Usually present

Wide

Absent

Usually stay inbetween

Flattened

Not remarkably elongate

Well developed

Present except some lower scombrids

Present in higher scombrids

Reduced in length

Fused with hypural in Acanthocybium,

Gymnosarda and some species of

Scomberomorus or separate

Forming a hypural plate

Absent or a shallow notch present

1 or 2

Absent

Absent except Gasterochisma

Flattened

Well developed

Between second and third neural spines 
Grammatorcynus and that $T$. robustus has retained many characters which its ancester had when the scombrid stem diverged from the gempylid stem. Rastrelliger, Scomber and Grammatorcynus, in other words, retain many primitive characters. Tongaichthys robustus, therefore, could be called a scombrid-like gempylid and Scomber, Rastrelliger and Grammatorcynus could be called gempylid-like scombrids. Lepidocybium also has many scombrid characters (Table 1). Munro (1943) placed it in the family Scomberomoridae (tribe Scomberomorini of the Scombridae of Collette and Russo, 1979) but then shifted it to the family Gempylidae (Munro, 1949). There seems to be an evolutionary path within the family Gempylidae toward the family Scombridae through Ruvettus, Lepidocybium, Thyrsitops and Tongaichthys. These have adapted to a pelagic fast swimming mode of life and have semifusiform body shapes; the other path is toward the family Trichiuridae through Gempylus, Diplospinus and Paradiplospinus. These have adapted to a mesopelagic and benthopelagic mode of life and have elongate body. These three families, the Gempylidae, Trichiuridae and Scombridae, comprise an apparently monophyletic group and can be considered as a superfamily of the Scombroidae. Although billfishes (Xiphiidae and Istiophoridae) have been often considered to be closely related to the Scombridae, we prefer to place them in another superfamily which may be a sister group of the Scombroidae. We are presently studying this problem. We also recognize that Epinnula and Neoepinnula of the family Gempylidae share a considerable number of characters with the family Scombrolabracidae and with the lower percoids, such as the Percichthyidae and Scombropidae, but this is beyond the scope of this study.

Considering the condition of hypural plate with caudal fin rays, the increasing number of principal caudal fin rays, the semifusiform of body, the expanding of the branchial area (large head) and the condition of the partly ossified gill rays, $T$. robustus seems to have the considerable ability for high-speed swimming as scombrids do.

\section{Acknowledgments}

We are grateful to Capt. T. Takahashi, the chief scientist Dr. Hideo Kohno and the crew of R.V. Kaiyo Maru for obtaining material. We thank Dr. Bruce B. Collette and Mr. Joseph L. Russo of the Systematics Laboratory, U.S. National Marine Fisheries Service, Dr. Robert H. Gibbs, Jr. of the U.S. National Museum of Natural History, Smithsonian Institution, and Dr. Teruya Uyeno of the National Science Museum (Natural History Institute) for critical review of the manuscript. The technical assistance of Ms. Reiko Nakamura who made the radiographs, clearing and staining specimens, a part of illustrations, and typing the manuscript is acknowledged.

The senior author (IN) is grateful to the Smithsonian Institution for providing him a postdoctoral fellowship in 1981, which made it possible to use extensive preserved specimens and clearing and staining specimens for the comparison. 


\section{Summary}

A new genus and species of gempylid fish was discovered in collections by R.V. Kaiyo Maru. Tongaichthys robustus n. gen., n. sp. described herein occurs from the Tonga Ridge area in the South Pacific. This species possesses both gempylid and scombrid characteristics and could be important in considering interrelationships between Gempylidae and Scombridae. Therefore, its osteological features are described in detail.

\section{Literature cited}

Collette, B.B. 1978. Adaptations and systematics of the mackerels and tunas. in G.D. Sharp and A.E. Dizon (eds.). The physiological ecology of tunas. Academic Press, New York: 7-39.

Collette, B.B. and L.N. Chao. 1975. Systematics and morphology of the bonitos (Sarda) and their relatives (Scombridae, Sardini). Fish Bull., U.S. 73(3): 516-625.

Collette, B.B. and J.L. Russo. 1979. An introduction to the Spanich mackerels, genus Scomberomorus. in E.L. Nakamura and H.R. Bullis, Jr. (eds.). Proceedings of a Colloquium on the Spanish and king mackerel resources of the Gulf of Mexico. Gulf Sta. Mar. Fish. Comm. (4): 3-16.

Fraser-Brunner, A. 1950. The fishes of the family Scombridae. Ann. Mag. Nat. Hist., ser. 12, 3: $131-163$.

Hubbs, C.L. and K.F. Lagler. 1958. Fishes of the Great Lakes region. (Rev. ed.). Cranbrook Inst. Sci. Bull. 26: 213 p.

Johnson, G.D. 1980. The limits and relationships of the Lutjanidae and associated families. Bull. Scripps Inst. Oceanog. 24: 1-114.

Kishinouye, K. 1923 . Contributions to the comparative study of the so-called scombroid fishes. J. Coll. Agric., Imp. Univ. Tokyo 8: 293-475.

Matsubara, K. and T. Iwai. 1952. Studies on some Japanese fishes of the family Gempylidae. Pacific Science 6(3): 193-212.

Matsubara, K. and T. Iwai. 1958. Anatomy and relationships of the Japanese fishes of the family Gempylidae. Mem. Coll. Agr., Kyoto Univ. Spec. No.: 23-54.

Munro, I.S.R. 1943. Revision of Australian species of Scomberomorus. Mem. Queensland Mus. 12(2): 65-95.

Munro, I.S.R. 1949. The rare gempylid fish, Lepidocybium flavobrunneum (Smith). Proc. Roy. Soc. Queensland 60(3): 31-41.

Nakamura, I., E. Fujii and T. Arai. 1983. First record of the gempylid, Nesiarchus nasutus from Japan and the Sulu Sea. Jap. J. Ichthyol. (in press).

Nybelin, O. 1973. Comments on the caudal skeleton of actinopterygians. 369-372. In P.H. Greenwood, R.S. Miles and C. Patterson (eds.). Interrelationships of fishes. Academic Press, London, $536 \mathrm{p}$.

Parin, N.V. and V.E. Bekker. 1972. Materials on taxonomy and distribution of some trichiuroid fishes (Pisces, Trichiuroidae: Scombrolabracidac, Gempylidac, Trichiuridae). Trudy Inst. Okean. SSSR Akad. Nauk 93: 110-204.

Regan, C.T. 1909. On the anatomy and classification of the scombroid fishes. Ann. Mag. Nat. Hist., ser. 8, 3: 66-75.

Starks, E.C. 1910. The osteology and mutural relationships of the fishes belonging to the family Scombridae. J. Morphology 21: 77-99. 